\title{
Perbedaan Minat Wirausaha pada Mahasiswa Lima Universitas di Yogyakarta Dilihat dari Penggunaan Media Sosial
}

\author{
Charolin Dealola Mega Cahyani ${ }^{1}$ \\ ${ }^{1}$ Fakultas Ekonomi, Universitas Sanata Dharma Yogyakarta \\ charolinktb123@gmail.com
}

DOI: https://doi.org/10.24071/exero.v3i2.4302

\begin{abstract}
Abstrak
Penelitian ini memiliki tujuan untuk mengetahui ada tidaknya perbedaan minat wirausaha mahasiswa lima universitas di Yogyakarta dilihat dari penggunaan media sosial yang meliputi intensitas penggunaan media sosial, jumlah media sosial (jumlah akun dan jumlah jenis) dan jenis media sosial yang paling sering digunakan. Dalam penelitian ini, peneliti melibatkan 100 responden yang berasal dari Universitas Gadjah Mada, Universitas Islam Negeri Sunan Kalijaga, Universitas Sanata Dharma, Universitas Atma Jaya Yogyakarta dan Universitas Sarjanawiyata Tamansiswa. Teknik pengumpulan data yang digunakan adalah sampling incidental. Uji instrumen yang digunakan adalah independent sample t-test dan Anova satu jalur. Hasil dalam penelitian ini menumjukkan bahwa tidak ada perbedaan minat wirausaha mahasiswa lima universitas di Yogyakarta dilihat dari penggunaan media sosial.
\end{abstract}

Kata kunci: minat wirausaha, media sosial

\begin{abstract}
This study aims to find out whether the differences entrepreneurial interests in five university students Yogyakarta seen from the use of social media that include the intensity of use social media, the number of social media (number of accounts and number of types) and the types of social media that are most often used. In this research, researchers use 100 respondents who come from Gadjah Mada University, Sunan Kalijaga State Islamic University, Sanata Dharma University, Atma Jaya Yogyakarta University and Sarjanawiyata Tamansiswa University. The data collection technique used in this research is incidental sampling technique. The analysis technique used in this research is independent sample t-test and one way ANOVA. The results of this study indicate that there is no difference in the entrepreneurial interests in Yogykarta, judjing from the use of social media.
\end{abstract}

Keywords: entrepreneurial interests, social media

\section{Pendahuluan}

Berbagai negara di belahan dunia telah merasakan dampak era digitalisasi, tidak terkecuali Indonesia. Salah satu indikator dari era digitalisasi adalah kemajuan teknologi, khususnya internet. Hampir semua aktivitas sehari-hari saat ini dilakukan dengan menggunakan internet mulai dari bermain, belajar, berkomunikasi hingga berbelanja. Hal tersebut menyebabkan kebutuhan akan internet di masa sekarang meningkat tajam. Menurut Kartajaya (2008) dalam Kurniawan dan Harti (2013) jaringan internet merupakan jaringan komputer yang mampu menghubungkan komputer di seluruh dunia sehingga informasi dalam berbagai jenis dan dalam berbagai bentuk dapat dikomunikasikan antar belahan dunia secara instan dan global. 
Menurut hasil survei dari Asosiasi Penyelenggara Jasa Internet Indonesia (AJPII) tahun 2017, pertumbuhan pengguna internet di Indonesia meningkat tajam dari 500.000 pengguna pada tahun 1998 menjadi lebih dari 143 juta pengguna pada tahun 2017 (https://apjii.or.id, 2019). Kebutuhan akan komunikasi dan informasi bagi seluruh masyarakat khususnya mahasiswa mendorong perkembangan internet sehingga melahirkan berbagai macam media sosial yang dapat semakin membantu mempermudah komunikasi dan memperoleh informasi. Berdasarkan hasil riset Wearesocial Hootsuite (2019), pengguna media sosial di Indonesia mencapai 150 juta atau sebesar $56 \%$ dari total populasi. Sementara pengguna media sosial mobile mencapai 130 juta atau sekitar $48 \%$ dari populasi. Mahasiswa sebagai generasi muda merupakan salah satu kelompok yang aktif menggunakan media sosial. Hal tersebut dapat diketahui dari data yang menyatakan bahwa pengguna internet terbesar berada di usia 18-34 tahun (wearesocial.com, 2019), dengan pengguna paling banyak yaitu laki-laki sebesar 51,43\%.

We Are Social juga mengungkapkan bahwa rata-rata orang Indonesia mengakses media sosial selama 3 jam 23 menit per hari dan jenis media sosial yang paling sering digunakan adalah YouTube (Kompas.com, 2019). Selain Youtube, ada juga Whatsapp, Facebook, dan Instagram yang banyak digunakan oleh masyarakat Indonesia. Saat ini setiap orang selalu ingin terhubung satu sama lain sehingga Kartajaya (2008) dalam Kurniawan dan Harti (2013) memiliki jargon tersendiri bagi penikmat media sosial. Ia mengatakan "mangan ora mangan sing penting connect" yang artinya walaupun tidak makan yang penting selalu terhubung.

Dewasa ini penggunaan media sosial telah mengalami pergeseran. Banyak pihak yang memanfaatkan media sosial untuk berbisnis secara online. Menurut socialmediaku.com (dalam Indoworo, 2016), peran media sosial semakin diakui dalam mendongkrak kinerja bisnis ataupun merek. Efektifitas pemanfaatannya tergantung pada bagaimana pemilik merek menggunakannya. Sturbucks, Dell, Levi's, dan Apple merupakan beberapa merek global yang menuai kesuksesan karena memanfaatkan media sosial. Di Indonesia, beberapa merek seperti Pocary Sweat, Nutrisari, Acer, XL, serta bisnis camilan keripik pedas Maicih juga berhasil memperbesar bisnisnya melalui peran media sosial. 
Sandeni (2012) dalam Kurniawan dan Harti (2013) menyatakan bahwa penjualan melalui internet dapat menjaring pembeli lebih luas karena tidak ada lagi batasan waktu dan tempat. Selama website yang menggantikan tugas kita berpromosi tetap online dan bisa diakses, selama itu pula produk kita akan siap menghasilkan penjualan. Penggunaan media sosial sesungguhnya dapat memangkas berbagai anggaran yang dapat memberatkan. Misalnya biaya untuk membangun toko dan membayar karyawan.

Dalam rangka meningkatkan kemajuan, Indonesia perlu menyelesaikan permasalahan perekonomian yang salah satu penyebabnya berasal dari pengangguran. Meskipun menurut BPS (2019), saat ini tingkat pengangguran di Indonesia telah mengalami penurunan sebanyak lima puluh ribu orang yang artinya jumlah wirausahawan di dalam negeri telah mencapai angka 3,1\% dari total populasi penduduk. Namun, jika dibandingkan dengan negara-negara di ASEAN, Indonesia masih menjadi negara yang tinggi tingkat penganggurannya (cnbcindonesia.com, 2019).

Mahasiswa sebagai intelektual muda yang sebagian besar sudah melek Informasi dan Teknologi (IT), seharusnya dapat memanfaatkan peluang ini menjadi kenyataan (Kurniawan dan Harti, 2013). Menurut Kurnianto dan Putra (2012) dalam Kurniawan dan Harti (2013), minat berwirausaha pada mahasiswa dapat ditumbuhkembangkan mulai dari bangku kuliah. Minat menjadi hal yang penting untuk didorong tumbuhkembangnya karena minat adalah suatu disposisi yang terorganisir melalui pengalaman yang mendorong seseorang untuk memperoleh objek khusus, aktivitas, pemahaman dan keterampilan untuk tujuan perhatian atau pencapaian.

Penulis melihat bahwa media sosial dapat menjadi salah satu penunjang tumbuhnya minat wirausaha pada mahasiswa sehingga penelitian ini bertujuan untuk mengetahui tentang penggunaan media sosial dan ada tidaknya perbedaan minat wirausaha pada mahasiswa lima universitas di Yogyakarta (UGM, UIN, USD, UAJY dan UST) dilihat dari penggunaan media sosial. Penggunaan media sosial meliputi intensitas penggunaan media sosial, jumlah media sosial (jumlah akun dan jumlah jenis) dan jenis media sosial yang paling sering digunakan. 


\section{Kajian Literatur}

\section{Minat Wirausaha}

Menurut Yanto (2010) dalam Afriyani (2015:14), minat berwirausaha adalah kemampuan untuk memberanikan diri dalam memenuhi kebutuhan hidup, memajukan usaha, atau menciptakan usaha baru dengan kekuatan yang ada pada diri sendiri. Menurut Santoso (1993) dalam Afriyani (2015:14), minat berwirausaha adalah keinginan, ketertarikan, serta kesediaan untuk bekerja keras atau berkemauan keras untuk berdikari atau berusaha memenuhi kebutuhan hidupnya tanpa merasa takut dengan resiko yang akan terjadi, serta senantiasa belajar dari kegagalan yang dialami. Dari dua definisi tersebut dapat disimpulkan bahwa minat wirausaha merupakan perasaan suka yang memotivasi seseorang untuk memperoleh informasi, aktivitas, pemahaman, dan ketrampilan untuk menjadi wirausahawan.

\section{Indikator Minat Wirausaha}

Menurut Safari (2003) dalam Rahayu (2015), indikator minat terdiri dari:

\section{Perasaan Senang}

Jika seseorang memiliki perasaan senang atau suka terhadap sesuatu maka ia akan terus mempelajari ilmu tentang berbagai hal yang disenanginya tanpa ada perasaan terpaksa.

2. Ketertarikan

Ketertarikan berhubungan dengan gaya gerak yang mendorong untuk cenderung merasa tertarik pada orang, benda, kegiatan, atau bisa berupa pengalaman afektif yang dirangsang oleh kegiatan itu sendiri.

3. Perhatian

Perhatian merupakan konsentrasi atau aktivitas jiwa terhadap pengamatan dan pengertian, dengan mengesampingkan yang lain daripada itu.

4. Keterlibatan

Ketertarikan seseorang akan suatu objek yang mengakibatkan orang tersebut senang atau tertarik untuk melakukan atau mengerjakan kegiatan objek tersebut.

Schiffman dan Kanuk (1994) dalam Kurniawan dan Harti (2013) menyatakan bahwa pengukuran minat terhadap pekerjaan dapat dilakukan dengan berbagai cara, 
salah satunya dengan struktur pembentukan minat berperilaku yaitu:

1. Komponen kognitif, yaitu pengetahuan dan persepsi yang diperoleh melalui pengalaman dengan suatu obyek, sikap, dan informasi dari berbagai sumber.

2. Komponen afektif, menggambarkan perasaan dan emosi seseorang terhadap obyek.

3. Komponen konatif, menunjukkan tindakan seseorang atau kecenderungan perilaku terhadap suatu obyek.

\section{Faktor-faktor Pendorong Pertumbuhan Minat Wirausaha}

McClelland (1961) dalam Basrowi (2011) mengemukakan bahwa kewirausahaan ditentukan oleh motif berprestasi, optimisme, sikap-sikap nilai, dan status kewirausahaan atau keberhasilan. Perilaku kewirausahaan dipengaruhi oleh faktor internal dan eksternal. Faktor-faktor itu adalah hak kepemilikan, kemampuan/kompetensi, dan insentif, sedangkan faktor eksternalnya meliputi lingkungan, dan media sosial merupakan salah satu faktor eksternal yang memicu kewirausahaan

Zimmerer (2008) dalam Kurniawan dan Harti (2013) menyatakan bahwa ada delapan faktor yang menjadi pendorong pertumbuhan minat wirausaha, yakni:

1. Pendapat bahwa wirausaha adalah seorang pahlawan

2. Pendidikan kewirausahaan

3. Faktor ekonomi dan kependudukan

4. Pergeseran dari ekonomi industry ke ekonomi jasa

5. Kemajuan teknologi

6. Gaya hidup bebas

7. E-commerce dan the World Wide Web

8. Terbukanya peluang bisnis internasional.

Menurut Hendro (2011:29), ada beberapa faktor yang menstimulus semangat kewirausahaan, yaitu:

1. Evolusi produk

Perubahan produk akan menimbulkan perubahan kebutuhan yang memunculkan sebuah peluang baru. 
2. Evolusi ilmu pengetahuan

Perubahan ilmu pengetahuan akan menimbulkan inspirasi produk baru.

3. Perubahan gaya hidup, selera dan hobi

Perubahan gaya hidup akan menimbulkan keinginan akan produk yang berbeda.

4. Perubahan teknologi

Berkembangnya teknologi dan semakin canggihnya teknologi akan menciptakan produk, suasana, dan gaya hidup yang berbeda.

5. Perubahan budaya

Berkembangnya gaya hidup, pendapatan, selera, teknologi dan sebagainya akan mengubah budaya seseorang, sehingga hal ini mempengaruhi kebutuhan akan produk yang berbeda di setiap tempat.

6. Perubahan struktur pemerintahan dan politik

Perubahan politik akan mempengaruhi perubahan struktur pemerintahan, yang berujung pada perubahan peraturan, kebijakan, dan arah perekonomian, sehingga muncul sebuah gap kebutuhan akan produk yang lalu dan paska perubahan.

\section{Intrapreneurship}

Kemampuan intrapreneurship (entrepreneurship di dalam sebuah perusahaan internal) yang semakin baik dan kuat akan memunculkan gairah entrepreneur. Hal ini disebabkan oleh kreativitas, inovasi, ketatnya persaingan, hasrat ingin tantangan yang lebih baru, dan perubahan organisasi. Jadi, organisasi secara tidak langsung mengembangkan jiwa entrepreneurship seseorang.

\section{Media Sosial}

Kartajaya (2008) dalam Kurniawan dan Harti (2013) menjelaskan bahwa media sosial adalah perpaduan sosiologi dan teknologi yang mengubah monolog (one to many) menjadi dialog (many to many) dan demokrasi informasi yang mengubah orang-orang dari pembaca konten menjadi penerbit konten. Media sosial menjadi sangat popular karena memberikan kesempatan bagi orang-orang untuk terhubung di dunia online dalam bentuk hubungan personal, politik, dan kegiatan bisnis.

Menurut Ardiyanto dalam Afriyani (2015:40), media sosial online disebut juga jejaring sosial online bukan media masa online, karena media sosial memiliki 
kekuatan sosial yang sangat mempengaruhi opini publik yang sangat berkembang di masyarakat. Penggalangan dukungan atau gerakan masa bisa terbentuk karena kekuatan media online sebab apa yang ada di media sosial terbukti mampu membentuk dan mempengaruhi opini, sikap, dan perilaku publik atau masyarakat. Sejalan dengan pernyataan tersebut, Pratama (2014) dalam Afriyani (2015:40) juga menyatakan bahwa media sosial lebih mengacu kepada media yang disediakan oleh pencipta atau pengembang aplikasi atau penyedia layanan pada pengguna, dengan tujuan untuk memberikan pengguna ruang dan media agar dapat bersosialisasi atau berinteraksi secara online dengan memanfaatkan jaringan komputer (internet) berbasiskan OTT (over the top) melalui perangkat mobile atau perangkat terhubung lainnya. Kaplan dan Haenlein (2010) dalam Nova (2018:4) mendefinisikan media sosial sebagai sebuah kelompok aplikasi berbasis internet yang dibangun atas dasar ideologi dan teknologi Web 2.0 dan yang memungkinkan penciptaan dan pertukaran "user-generated content"

Dari penjelasan tersebut dapat diketahui bahwa media sosial memberikan banyak kemudahan bagi para penggunanya mulai dari berkomunikasi, berbagi informasi, dan menciptakan sesuatu yang dapat berkembang di masyarakat. Selain itu, media sosial juga dapat digunakan sebagai media untuk mengekspresikan diri, bisnis, dan pemasaran produk. Oleh sebab itu, adanya media sosial diharapkan dapat meningkatkan minat wirausaha dan banyaknya jenis media sosial diharapkan dapat memudahkan masyarakat untuk melakukan bisnis sejalan dengan kemajuan teknologi.

\section{Jenis-jenis Media Sosial}

Kaplan dan Haenlein (2010) dalam Kurniawan dan Harti (2013) mengklasifikasikan media sosial menjadi enam jenis yaitu:

1. Kolaborasi proyek

Ada dua sub kategori dalam jenis media sosial yaitu wiki dan aplikasi bookmark sosial. Wiki adalah situs yang memungkinkan pengguna untuk menambah, menghapus, dan mengubah konten bersbasis teks. Contoh wiki yang dapat kita temui adalah Wikipedia (wikipedia.com). Subkategori lainnya adalah aplikasi bookmark sosial, yang memungkinkan pengumpulan berbasis kelompok 
dan rating link internet atau konten media, contohnya adalah (reddit.com) dimana link dan postingan dinilai oleh pengguna. Proyek kolaborasi menjadi sumber utama informasi bagi banyak konsumen. Oleh sebab itu, penting bagi perusahaan untuk memberi informasi yang tepat mengenai perusahaan di dalam kolaborasi proyek tersebut.

2. Blog

Blog merupakan situs web yang menyampaikan ekspresi, pendapat, ataupun pengalaman dari penulis. Pengguna lebih bebas dalam mengekspresikan sesuatu di blog, seperti kritikan terhadap kebijakan pemerintah. Sebuah blog dapat mencakup teks, gambar, dan video. Beberapa situs yang menjadi tempat posting gratis bagi para blogger yaitu salah satunya adalah (blogspot.com)

3. Konten masyarakat

Tujuan utama dari konten masyarakat adalah untuk berbagi konten-konten media antar pengguna. Konten bisa apa saja seperti situs berbagi foto seperti Flickr, situs berbagi video seperti YouTube. Di lain pihak, pengguna internet saat ini mengharapkan suatu konten dimana ia bisa dengan bebas berekspresi, dan ini merupakan peluang untuk memasarkan diri agar dapat menghasilkan banyak kepentingan dengan biaya minimal.

4. Situs jejaring sosial

Situs jejaring sosial merupakan aplikasi yang memungkinkan pengguna untuk terhubung dengan menggunakan profil pribadi. Profil pribadi dapat mencakup semua jenis informasi termasuk foto, video, file audio, dan blog. Situs jejaring sosial umumnya mencakup fitur seperti instant messaging dan e-mail. Situs jejaring sosial dapat membantu pengguna membuat jaringan. Perusahaan dapat mengembangkan merek mereka dengan menciptakan kehadiran untuk merek mereka dalam masyarakat serta menjaganya tetap aktif. Beberapa contoh situs jejaring sosial adalah Facebook, Twitter, dan Instagram.

5. Dunia game virtual

Dunia game virtual yaitu lingkungan tiga dimensi dimana pengguna dapat berinteraksi menggunakan avatar pribadi. Dunia game virtual umumnya memiliki seperangkat aturan ketat yang harus diikuti dalam konteks peran Multiplayer Massively Online bermain game. Permainan yang paling populer dalam kategori 
ini termasuk world of warcraft dan everquest. Melalui game-game ini seseorang dapat memperoleh lebih banyak popularitas yang dapat digunakan untuk menarik pasar tertentu.

6. Dunia sosial virtual

Dunia sosial virtual merupakan situs yang memungkinkan pengguna untuk berinteraksi dalam platform tiga dimensi menggunakan avatar dalam cara yang mirip dengan kehidupan asli, contohnya yaitu Second Life (secondlife.com). Uang yang digunakan dalam permainan Second Live dapat dikonversi menjadi uang yang sebenarnya ke rekening bank pengguna, jika perusahaan belajar untuk memanfaatkannya, dapat menjadi sumber nyata media income.

\section{Ciri-Ciri dan Karakteristik Media Sosial}

Menurut Kaplan dan Haenlin (2010) dalam Nova (2018:5), media sosial memiliki ciri-ciri sebagai berikut:

1. Pesan yang disampaikan tidak hanya untuk satu orang saja namun bisa kepada banyak orang.

2. Pesan yang disampaikan cenderung lebih cepat dibandingkan media lainnya.

3. Pesan yang disampaikan bebas, tanpa harus melalui Gatekeeper.

4. Penerima pesan yang menentukan waktu interaksi.

Mayfield (2008) dalam Kurniawan dan Harti (2013) menyatakan bahwa media sosial paling baik dipahami sebagai kelompok media online jenis baru yang berbagi sebagian atau semua karakteristik sebagai berikut:

1. Partisipasi, media sosial mendorong adanya kontribusi dan umpan balik dari setiap orang yang tertarik. Hal ini mengaburkan batas antara media dan penonton.

2. Keterbukaan, kebanyakan layanan media sosial terbuka untuk umpan balik dan partisipasi. Mereka mendorong adanya pembicaraan, komentar dan berbagi informasi. Jarang sekali terdapat hambatan untuk mengakses dan memanfaatkan konten-konten yang terdapat dalam media sosial.

3. Percakapan, media sosial menggunakan percakapan dua arah.

4. Komunitas, media sosial memungkinkan masyarakat untuk berkomunikasi secara efektif melalui pembentukan komunitas online. Masyarakat dapat selalu berbagi 
tentang apapun, seperti berbagi tentang film favorit atau isu politik yang sedang hangat.

5.Keterhubungan, sebagian besar jenis media sosial berkembang pada keterhubungan mereka. Mereka memanfaatkan link ke situs, beberapa sumber terpercaya serta ke teman-teman mereka. Keterhubungan adalah yang paling penting peranannya dalam media sosial dan membuat para pengguna merasa dimanjakan dengan fasilitas dapat terhubung walau tidak bertemu.

\section{Penggunaan Media Sosial Dan Minat Wirausaha}

Zimmerer (2008) dalam Kurniawan dan Harti (2013) menyatakan bahwa ada tujuh faktor yang mendorong pertumbuhan minat kewirausahaan, yakni:

1. Pendapat bahwa wirausaha adalah seorang pahlawan

2. Pendidikan kewirausahaan

3. Faktor ekonomi dan kependudukan

4. Pergeseran dari ekonomi industry ke ekonomi jasa

5. Kemajuan teknologi

6. Gaya hidup bebas

7. Terbukanya peluang bisnis international.

\section{Perumusan Hipotesis}

Perbedaan Minat Wirausaha Mahasiswa dilihat dari Intensitas Penggunaan Media Sosial

Perkembangan ilmu pengetahuan, sosial, ekonomi, politik, budaya, teknologi, dan kesejahteraan telah menciptakan gap di antara faktor-faktor yang mempengaruhi perkembangan tersebut. Misalnya gap antara ilmu pengetahuan dan sosial, sosial dan politik, budaya dan sosial, atau sosial dan teknologi. Gap yang terjadi akan menciptakan perubahan status sosial, perilaku, gaya hidup, kebutuhan, keinginan, selera, dan sebagainya, sehingga bisa membangkitkan sebuah inspirasi bisnis yang pada akhirnya memunculkan peluang bisnis. Munculnya peluang bisnis yang baru akan menstimulus munculnya wirausaha - wirausaha muda (Hendro, 2011: 28). Zimmerer (2008) dalam Kurniawan dan Harti (2013) menyatakan bahwa ada tujuh faktor yang mendorong pertumbuhan minat kewirausahaan, yakni pendapat bahwa 
wirausaha adalah seorang pahlawan, pendidikan kewirausahaan, faktor ekonomi dan kependudukan, pergeseran dari ekonomi industri ke ekonomi jasa, kemajuan teknologi, gaya hidup bebas, dan terbukanya peluang bisnis international.

Media sosial online disebut juga jejaring sosial online karena memiliki kekuatan sosial yang sangat mempengaruhi opini publik yang sangat berkembang di masyarakat. Penggalangan dukungan atau gerakan massa bisa terbentuk karena kekuatan media online sebab apa yang ada di media sosial terbukti mampu membentuk dan mempengaruhi opini, sikap, dan perilaku publik atau masyarakat.

Dalam penelitian yang dilakukan oleh Kurniawan dan Harti (2013) ditemukan bahwa ada pengaruh tingkat penggunaan sosial media terhadap minat berwirausaha pada mahasiswa Jurusan Pendidikan Ekonomi di Fakultas Ekonomi Universitas Negeri Surabaya. Selain itu, penelitian lain yang dilakukan oleh Afriyani (2015) menemukan bahwa penggunaan media sosial berpengaruh signifikan terhadap minat wirausaha.

Dunia dewasa saat ini banyak melibatkan kemajuan teknologi khususnya penggunaan media sosial dalam berbagai hal. Menurut penelitian yang dilakukan oleh We Are Social perusahaan media asal Inggris yang bekerja sama dengan Hootsuite, saat ini rata-rata orang Indonesia menghabiskan 3 jam 23 menit sehari untuk mengakses media sosial (Kompas.com, 2019).

Oleh sebab itu, penulis menduga bahwa seseorang yang semakin sering menggunakan media sosial akan menjadikan media tersebut sebagai salah satu rujukan informasi yang penting dari dirinya. Pada akhirnya keputusan menggunakan media sosial sebagai bagian dari kehidupan seseorang dapat mempengaruhi keinginan yang dirasakan untuk menjadi seorang wirausahawan karena intensitas penggunaan media sosial. Berdasarkan uraian tersebut dihipotesiskan bahwa: $\mathrm{H} 1$ = Terdapat perbedaan minat wirausaha mahasiswa lima universitas di Yogyakarta dilihat dari intensitas penggunaan media sosial

\section{Perbedaan Minat Wirausaha Mahasiswa dilihat dari Jumlah Akun dan Jumlah Jenis Media Sosial Yang Digunakan}

Kominfo menyampaikan bahwa jumlah pengguna internet di Indonesia saat ini mencapai 63 juta orang dan merupakan pengguna terbesar keempat di dunia. 
Sebagian besar pengguna yaitu 95\% memanfaatkan internet untuk mengakses jejaring sosial. Menurut penelitian yang dilakukan oleh We Are Social pada tahun 2019 (dalam Kompas.com, 2019), sebanyak 33\% pengguna internet merupakan kaum muda dengan rentang usia 18-24 tahun. Selain itu, masyarakat Indonesia juga gemar mengakses beberapa jenis media sosial seperti Youtube, Whatsapp, Facebook, dan Instagram. Dari data tersebut penulis mengasumsikan bahwa pengguna media sosial terutama mahasiswa memiliki lebih dari satu akun media sosial dan hal tersebut mampu menumbuhkan minat wirausaha pada mahasiswa. Pada saat melakukan interaksi di berbagai media sosial, para pengguna dapat melihat pengalaman dan aktivitas pelaku bisnis. Setelah melihat berbagai pengalaman dan informasi tersebut, maka dapat tumbuh minat wirausaha. Semakin banyak seseorang memiliki akun media sosial dan menggunakannya, maka semakin banyak seseorang tersebut memiliki sumber informasi yang tentunya dapat mempengaruhi minat seseorang terhadap dunia wirausaha. Adapun hipotesis dalam penelitian adalah $\mathrm{H} 2$ = Terdapat perbedaan minat wirausaha mahasiswa lima universitas di Yogyakarta dilihat dari jumlah akun dan jumlah jenis media sosial yang digunakan.

\section{Perbedaan Minat Wirausaha Mahasiswa dilihat dari Jenis Media Sosial Yang Paling Sering Digunakan}

Setiap jenis media sosial memiliki karakteristik yang berbeda-beda sehingga informasi yang disajikan juga dikemas dalam bentuk yang berbeda. Kaplan dan Haenlein (2010) Kurniawan dan Harti (2013) mendefinisikan media sosial sebagai kelompok berbasis aplikasi yang dibangun di atas fondasi ideologi dan teknologi Web 2.0 dan yang memungkinkan penciptaan dan pertukaran konten yang dibuat penggunanya. Selain itu, mereka juga mengklasifikasikan jenis-jenis media sosial sebagai kolaborasi proyek, blog, konten masyarakat, situs jejaring sosial, dunia game virtual, dan dunia social virtual. Perkembangan teknologi informasi menjadi peluang yang paling nyata dihadapi saat ini. We Are Social juga merilis data yang menyatakan bahwa dari 132,7 juta pengguna internet di Indonesia, 130 juta diantaranya pengguna aktif berbagai jenis media sosial seperti Facebook, Instagram, dan Twitter dengan penetrasi sebesar $49 \%$. Pertumbuhan pengguna platform media sosial membuat banyak orang terpacu ide kreatifnya untuk mencari sumber penghasilan. Mereka 
memasarkan aneka produk kreatif dengan memanfaatkan jejaring pertemanan yang mereka miliki. Ada beragam produk, mulai dari fashion, perhiasan, sampai makanan dalam kemasan ditawarkan di sana. Dengan demikian terlihat bahwa peranan media sosial di dalam industri kreatif berpengaruh kepada tumbuhnya minat wirausaha seseorang. Berdasarkan uraian tersebut dihipotesiskan bahwa:

H3 = Terdapat perbedaan minat wirausaha mahasiswa lima Universitas di Yogyakarta dilihat dari jenis media sosial yang digunakan

\section{Rerangka konseptual}

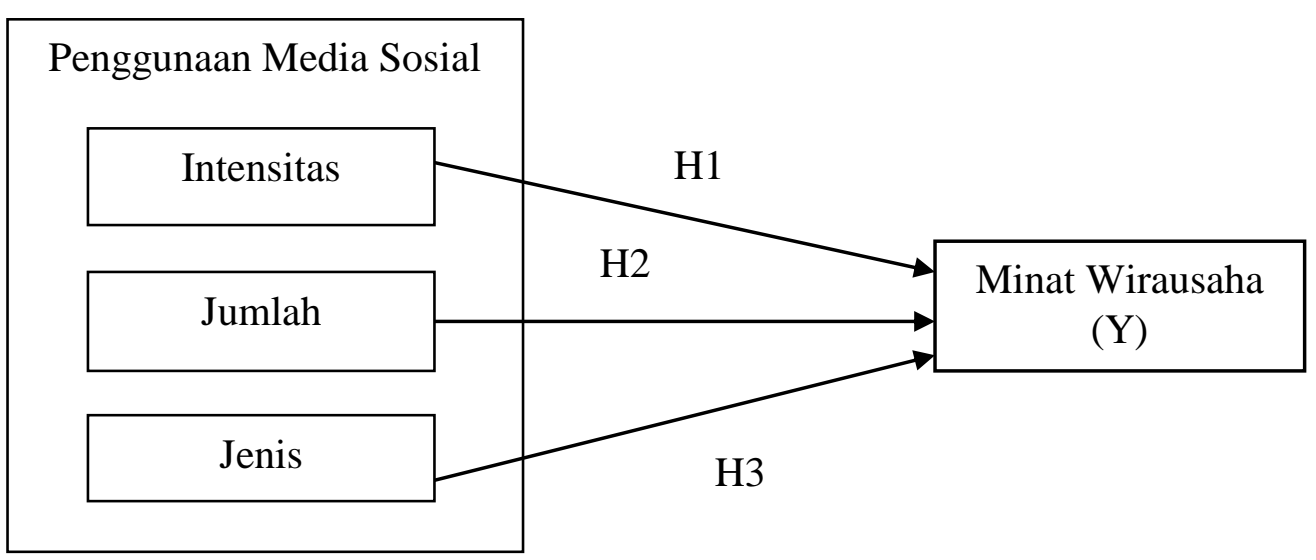

Gambar 1.

Kerangka konseptual penelitian

\section{Metode Penelitian}

Penelitian merupakan penelitian deskriptif dan komparatif. Penelitian deskriptif memiliki tujuan untuk menggambarkan karakter suatu variabel, kelompok atau gejala sosial yang terjadi (Martono, 2014:17). Sedangkan penelitian komparatif adalah penelitian yang membandingkan keadaan suatu variabel atau lebih pada dua atau lebih sampel yang berbeda, dengan teknik pengumpulan data kuantitatif (Sugiyono, 2018: 54). Penelitian kuantitatif menurut Martono (2014:20) memiliki empat varian, dari keempat varian tersebut peneliti mengunakan penelitian survei. Penelitian survei yaitu tipe penelitian dengan menggunakan kuesioner atau angket sebagai sumber data utama.

Pengumpulan data penelitian ini dilakukan dengan menyebarkan kuesioner pada tanggal 9 - 12 Desember 2019 dan dilanjutkan pada tanggal 14 -18 Februari 2020 di lima kampus yaitu Universitas Gadjah Mada, Universitas Islam Negeri 
Sunan Kalijaga, Universitas Sanata Dharma, Universitas Atma Jaya Yogyakarta, dan Universitas Sarjanawiyata Taman Siswa.

Penelitian ini memakai variabel bebas dan variabel terikat. Variabel bebasnya yaitu penggunaan media sosial yang meliputi intensitas penggunaan media sosial, jumlah media sosial yang digunakan dan jenis media sosial yang paling sering digunakan. Intensitas penggunaan media sosial berkaitan dengan waktu yaitu seberapa lama mahasiswa mengakses media sosial dalam sehari. Menurut Kompas.com saat ini rata-rata orang Indonesia menghabiskan tiga jam dua puluh tiga menit dalam sehari untuk mengakses media sosial. Jumlah akun media sosial yaitu seberapa banyak akun media sosial yang digunakan. Jumlah jenis media sosial yaitu seberapa banyak jenis media sosial yang digunakan. Jenis media sosial adalah media sosial apa yang paling sering digunakan. Variabel terikatnya adalah minat wirausaha. Menurut Schiffman dan Kanuk (1994) dalam Kurniawan dan Harti (2013) pengukuran minat terhadap pekerjaan dapat dilakukan dengan berbagai cara, salah satunya dengan struktur pembentukan minat berperilaku yaitu : 1) Komponen kognitif, yaitu pengetahuan dan persepsi yang diperoleh melalui pengalaman dengan suatu obyek, sikap dan informasi dari berbagai sumber, 2) Komponen Afektif, menggambarkan perasaan dan emosi seseorang terhadap obyek, dan 3) Komponen Konatif, menunjukkan tindakan seseorang atau kecenderungan prilaku terhadap suatu obyek.

Penelitian ini menggunakan skala Likert yang dimodifikasi dengan skala 1-4 yaitu Sangat Tidak Setuju (1), Tidak Setuju (2), Setuju (3), Sangat Setuju (4) dan menghilangkan alternatif jawaban netral. Menurut Hertanto (2017), hal ini dilakukan agar data penelitian lebih akurat karena kategori jawaban undeciden yang mempunyai arti ganda tidak digunakan di dalam kuesioner sehingga dapat menghilangkan kecenderungan central tendency effect pada jawaban para responden.

Populasi dalam penelitian ini adalah seluruh mahasiswa aktif dari Universitas Gadjah Mada, Universitas Islam Negeri Sunan Kalijaga, Universitas Sanata Dharma, Universitas Atma Jaya Yogyakarta, dan Universitas Sarjanawiyata Tamansiswa yang berjumlah 114.225 mahasiswa (https://forlap.ristekdikti.go.id, 2019). Lima universitas tersebut dipilih berdasarkan kategori kampus negeri dan swasta dengan berbasis agama dan non agama. Dalam penelitian diasumsikan bahwa saat ini semua 
mahasiswa menggunakan media sosial, sebab penelitian yang dilakukan oleh We Are Social menyatakan bahwa pengguna terbesar media sosial di Indonesia berasal dari kalangan usia 18 tahun sampai 24 tahun.

Sampel dalam penelitian ini adalah 100 mahasiswa pengguna media sosial yang terdiri dari 49 mahasiswa Universitas Gadjah Mada, 18 mahasiswa Universitas Islam Negeri Sunan Kalijaga, 11 mahasiswa Universitas Sanata Dharma, 11 mahasiswa Universitas Atma Jaya Yogyakarta, dan 11 mahasiswa Universitas Sarjanawiyata Tamansiswa. Jumlah sampel merujuk dari pernyataan Frankel dan Wallen (1993) dalam Indrawan dan Poppy (2017:103) yang menyarankan besar sampel minimum untuk penelitian deskriptif sebanyak 100 sampel. Pembagian sampel ditentukan dengan menggunakan kalkulator statistik online dengan tingkat kepercayaan $95 \%$ dan tingkat eror sebesar 10\%. Teknik sampling yang digunakan adalah sampling kuota dan insidental sampling. Menurut Sugiyono (2018:124) sampling kuota adalah teknik untuk menentukan sampel dari populasi yang mempunyai ciri-ciri tertentu sampai jumlah (kuota) yang diinginkan. Sedangkan incidental sampling merupakan teknik penentuan sampel berdasarkan kebetulan, siapa saja yang secara kebetulan/insidental bertemu dengan peneliti dapat digunakan sebagai sampel, bila dipadang orang yang kebetulan ditemui itu cocok sebagai sumber data (Sugiyono, 2018:125).

Data penelitian ini terdiri dari data primer dan data sekunder. Data primer didapatkan dari responden yang mengisi kuesioner pengaruh kecenderungan penggunaan media sosial terhadap minat wirausaha mahasiswa. Data sekunder digunakan untuk mengetahui sejarah dan visi misi dari lima universitas yang diteliti dan diperoleh dari website resmi setiap universitas.

Data yang sudah dikumpulkan melalui kuesioner diuji validitas dan reliabilitasnya. Selain itu, dilakukan juga analisis deskripsi respoden dan variabel. Analisis deskripsi respoden dibuat berdasarkan universitas, intensitas penggunaan media sosial setiap harinya, jumlah media sosial yang digunakan, dan jenis media sosial yang paling sering digunakan. Pada analisis deskriptif variabel, minat wirausaha dikategorikan menjadi 4 interval kelas dengan rumus Strurges yaitu

$$
C^{1}=\frac{\text { range }}{K}=\frac{4-1}{4}=0,75
$$

Keterangan: 


$$
\begin{aligned}
& C^{1} \quad=\text { Interval } \\
& \text { range }=\text { selisih batas atas dengan batas bawah } \\
& K \quad=\text { banyaknya kelas }
\end{aligned}
$$

Besarnya rentang skala pengukuran minat wirausaha adalah 0,75 . Hal ini berarti semakin tinggi rentang nilai maka dapat diartikan bahwa minat wirausaha semakin tinggi. Apabila nilai semakin rendah maka dapat diartikan bahwa minat wirausaha semakin rendah. Kategori nilai minat wirausaha adalah sebagai berikut:

Tabel 1. Kategori Nilai Minat Wirausaha

\begin{tabular}{ll}
\hline \multicolumn{1}{c}{ Rentang Nilai } & \multicolumn{1}{c}{ Penjelasan } \\
\hline $1,00-1,75$ & Minat wirausaha sangat rendah \\
$1,76-2,50$ & Minat wirausaha rendah \\
$2,51-3,25$ & Minat wirausaha tinggi \\
$3,26-4,00$ & Minat wirausaha sangat tinggi \\
\hline
\end{tabular}

Selain analisis deskripsi responden dan variabel, dilakukan juga pengujian hipotesis dengan independent sampel t-test dan Anova satu jalur. Independent sampel t-test digunakan untuk menguji perbedaan minat wirausaha mahasiswa lima universitas di Yogyakarta dilihat dari intensitas penggunaan media sosial. Anova satu jalur digunakan untuk menguji perbedaan minat wirausaha mahasiswa lima universitas di Yogyakarta dilihat dari jumlah akun media sosial yang digunakan, jumlah jenis media sosial yang digunakan, dan jenis media sosial yang paling sering digunakan.

\section{Hasil dan Pembahasan}

\section{Hasil Pengujian Instrumen}

\section{Uji Validitas}

Uji validitas dilakukan untuk mengetahui valid tidaknya instrumen penelitian. Menurut Hasan (2006) dalam (Yahmini, 2018:42) validitas berarti kesucian alat ukur dengan apa yang hendak diukur, atau dalam arti lain validitas merupakan alat yang dapat mengukur hal atau subjek yang ingin diukur. Uji ini dilakukan terhadap 9 pernyataan yang telah diisi oleh 100 responden dengan menggunakan korelasi Pearson Product Moment, yaitu membandingkan nilai $\mathbf{r}_{\text {hitung }}$ dengan nilai $\mathbf{r}_{\text {tabel. }}$. Pada $\alpha$ 
sebesar 5\% diperoleh nilai $\mathrm{r}_{\text {tabel }}$ sebesar 0,1966. Hasil uji validitas dapat dilihat pada tabel 2 berikut ini:

Tabel 2. Hasil Uji Validitas

\begin{tabular}{cccccc}
\hline Variabel & Dimensi & Item & $\mathrm{r}_{\text {hitung }}$ & $\mathrm{r}_{\text {tabel }}$ & Status \\
\hline & \multirow{2}{*}{ Kognitf } & 1 & $0,695^{* *}$ & 0,1966 & VALID \\
& & 3 & $0,605^{* *}$ & 0,1966 & VALID \\
Minat & \multirow{2}{*}{ Afektif } & 4 & $0,644^{* *}$ & 0,1966 & VALID \\
Wirausaha & & $0,833^{* *}$ & 0,1966 & VALID \\
& & 6 & $0,696^{* *}$ & 0,1966 & VALID \\
& \multirow{2}{*}{ Konatif } & 7 & $0,659^{* *}$ & 0,1966 & VALID \\
& & 8 & $0,630^{* *}$ & 0,1966 & VALID \\
& & 9 & $0,777^{* *}$ & 0,1966 & VALID \\
& & $0,775^{* *}$ & 0,1966 & VALID \\
\hline
\end{tabular}

Sumber : Data primer diolah, tahun 2020

Berdasarkan tabel 2 diketahui bahwa seluruh butir pernyataan yang berkaitan dengan variabel minat wirausaha mempunyai nilai $r$ hitung $>r$ tabel sehingga semua butir pernyataan dikatakan valid dan dapat digunakan dalam penelitian.

\section{Uji Reliabilitas}

Uji reliabilitas dalam penelitian ini menggunakan teknik Cronbach's Alpha. Jika nilai Cronbach's Alpha > 0,60 maka variabel dinyatakan reliabel atau konsisten namun jika nilai Cronbach's Alpha $<0,60$ maka variabel dinyatakan tidak reliabel atau konsisten. Nilai Cronbach's Alpha variabel minat wirausaha adalah 0,872 sehingga lebih besar dari 0,6 dan dikatakan reliabel.

\section{Analisis Deskriptif Responden}

Tujuan analisis ini adalah untuk mengetahui berbagai data yang berkaitan dengan identitas responden. Penelitian ini mengambil data 100 responden dari lima universitas di Yogyakarta, yaitu Universitas Gadjah Mada sebanyak 49 mahasiswa atau 49\%, Universitas Islam Negeri Sunan Kalijaga sebanyak 18 mahasiswa atau 18\%, dan Universitas Sanata Dharma, Universitas Atma Jaya Yogyakarta, Universitas Sarjana Wiyata Taman Siswa masing-masing sebanyak 11 mahasiswa atau $11 \%$. Jika dilihat berdasarkan intensitas penggunaan media sosial maka terdapat 78 mahasiswa atau $78 \%$ yang intensitas penggunaan media sosialnya rata-rata 3 jam atau lebih per hari dan sisanya 22 mahasiswa atau $22 \%$ intensitas penggunaan media sosialnya kurang dari 3 jam/hari. 
Jumlah media sosial yang digunakan dibagi menjadi dua bentuk, yaitu jumlah akun media sosial yang digunakan dan jumlah jenis media sosial yang digunakan. Menurut jumlah akun media sosial yang digunakan maka jumlah responden yang memiliki jumlah akun media sosial lebih dari 4 yaitu sebanyak 36 mahasiswa atau $36 \%$, responden yang memiliki satu jumlah akun media sosial sebanyak 14 mahasiswa atau 14\%, responden yang memiliki 2 jumlah akun sebanyak 12 mahasiswa atau 12\%, responden yang memiliki 3 jumlah akun media sosial sebanyak 17 mahasiswa atau $17 \%$, dan responden yang memiliki 4 jumlah akun sebanyak 21 mahasiswa atau $21 \%$. Selanjutnya menurut jumlah jenis media sosial yang digunakan maka responden yang memiliki jumlah jenis media sosial yang lebih dari empat sebanyak 32 mahasiswa atau 32\%, responden yang memiliki satu jumlah jenis media sosial sebanyak 8 mahasiswa atau $8 \%$, responden yang memiliki dua jumlah jenis media sosial sebanyak 12 mahasiswa atau 12\%, responden yang memiliki 3 jumlah jenis media sosial sebanyak 24 mahasiswa atau 24\%, dan responden yang memiliki 4 jumlah jenis media sosial sebanyak 24 mahasiswa atau $24 \%$.

Menurut jenis media sosial yang digunakan, responden yang menggunakan WhatsApp dan Line sebanyak 45 mahasiswa atau 45\%. Pada urutan kedua pengguna terbanyak yaitu jenis media sosial Instagram, sebanyak 39 mahasiswa atau 39\%, disusul YouTube sebanyak 10 mahasiswa atau 10\%, lalu Twitter sebanyak 5 mahasiswa atau 5\%, di urutan terakhir yang menandakan bahwa jenis media sosial tersebut paling sedikit digunakan yaitu Facebook sebanyak 1 mahasiswa atau $1 \%$.

\section{Analisis Deskriptif Variabel Minat Wirausaha}

Tabel 3. Deskiptif Variabel Minat Wirausaha

\begin{tabular}{|c|c|c|c|}
\hline Komponen & Pernyataan & Mean & Mean \\
\hline \multirow{3}{*}{ Kognitif } & $\begin{array}{l}\text { Suka membaca, menonton, dan mendengar hal-hal } \\
\text { terkait wirausaha }\end{array}$ & \multirow{3}{*}{2,967} & 2,9 \\
\hline & Mengetahui manfaat wirausaha & & 3,09 \\
\hline & Memiliki pengetahuan terkait wirausaha & & 2,91 \\
\hline \multirow{2}{*}{ Afektif } & $\begin{array}{l}\text { Merasa bersemangat saat melakukan berbagai hal } \\
\text { yang berkaitan dengan wirausaha. }\end{array}$ & \multirow{2}{*}{3,085} & 3,01 \\
\hline & $\begin{array}{l}\text { Timbul keinginan untuk terlibat langsung ketika } \\
\text { ada teman yang bercerita sedang merintis usaha }\end{array}$ & & 3,16 \\
\hline \multirow{3}{*}{ Konatif } & Bertanya pada siapapun terkait tentang wirausaha. & \multirow{3}{*}{3,1625} & 2,99 \\
\hline & Sering membayangkan memiliki usaha sendiri. & & 3,38 \\
\hline & Mencoba melakukan kegiatan wirausaha & & 3,05 \\
\hline
\end{tabular}


Berusaha untuk memiliki usaha sendiri sekecil apapun bentuk usahanya.

Mean 3,08

Sumber : Data primer diolah, tahun 2020

Penelitian ini menggunakan tiga komponen untuk mengukur minat wirausaha mahasiswa yaitu komponen kognitif, afektif, dan konatif. Berdasarkan tabel 3 dapat dilihat bahwa rata-rata skor dari semua pernyataan terkait minat wirausaha mahasiswa secara umum adalah sebesar 3,08 yang berarti mahasiswa memiliki minat yang tinggi untuk melakukan wirausaha. Rata-rata skor tertinggi adalah 3,38 pada pernyataan terkait komponen konatif yaitu mahasiswa "sering membayangkan memiliki usaha sendiri”. Pada urutan selanjutnya, pernyataan komponen konatif bahwa mahasiswa telah "berusaha untuk memiliki usaha sendiri sekecil apapun bentuk usahanya" memiliki rata-rata skor sebesar sebesar 3,23. Urutan ketiga dengan rata-rata skor sebesar 3,16 terdapat pada komponen afektif yang menyatakan bahwa mahasiswa "timbul keinginan untuk terlibat langsung ketika ada teman yang bercerita sedang merintis usaha”. Berdasarkan uraian tersebut dapat dilihat bahwa mahasiswa tertarik untuk memiliki usaha pribadi dengan menyatakan keinginan untuk terlibat langsung ketika orang lain sedang merintis usaha. Selain itu, mahasiswa telah berusaha aktif dalam bentuk tindakan untuk berlatih berwirausaha.

\section{Uji Asumsi}

Uji asumsi terdiri dari uji normalitas dan uji homogenitas. Hasil uji normalitas menunjukkan bahwa semua data terdistribusi normal karena mimiliki nilai Sig. > 0,05. Hasil uji homogenitas juga menyatakan bahwa semua data memiliki sifat homogen karena nilai signifikansi lebih dari 0,05.

\section{Independent Sampel T-test}

Independent sampel t-test digunakan untuk menguji perbedaan minat wirausaha mahasiswa lima universitas di Yogyakarta dilihat dari intensitas penggunaan media sosial. Hasil pengujian dapat pada tabel 4 berikut ini: 
Tabel 4. Hasil Uji Independent Sampel T-test Minat Wirausaha Berdasarkan Intensitas Penggunaan Media Sosial

\begin{tabular}{cccc}
\hline \multirow{2}{*}{$\begin{array}{c}\text { Minat } \\
\text { Wirausaha }\end{array}$} & $\begin{array}{c}\text { Nilai rata-rata intensitas } \\
\text { penggunaan media sosial } \\
\text { kurang dari 3 jam/hari }\end{array}$ & $\begin{array}{c}\text { Nilai rata-rata intensitas } \\
\text { penggunaan media sosial } \\
\text { 3 jam atau lebih/hari }\end{array}$ & $\begin{array}{c}\text { Sig (2- } \\
\text { tailed) }\end{array}$ \\
\cline { 2 - 4 } & 3,155 & 3,059 & 0,377 \\
\hline
\end{tabular}

Sumber : Data Primer, diolah tahun 2020

Langkah-langkah uji independent sampel t-test adalah:

1. Menetapkan hipotesis nol $\left(\mathrm{H}_{0}\right)$ dan hipotesis alternatif $\left(\mathrm{H}_{1} / \mathrm{H}_{\mathrm{a}}\right)$

$\mathrm{H}_{01}: \mu 0 a=\mu 0 b$, tidak ada perbedaan minat wirausaha mahasiswa lima Universitas di Yogyakarta dilihat dari intensitas penggunaan media sosial

$\mathrm{H}_{\mathrm{a} 1}: \mu 1 a \neq \mu 1 b$, ada perbedaan minat wirausaha mahasiswa lima Universitas di Yogyakarta dilihat dari intensitas penggunaan media sosial

2. Memilih tingkat signifikansi $(\alpha)$

Tingkat signifikansi yang digunakan dalam penelitian ini yaitu $\alpha=0,05$.

3. Menentukan kriteria pengujian

Jika pSig $\geq \alpha$ maka Ho diterima dan Ha ditolak

Jika pSig $<\alpha$ maka Ho ditolak dan Ha diterima

4. Mengambil kesimpulan

Berdasarkan tabel 4, dapat dilihat bahwa nilai Sig. (2-tailed) untuk intensitas pengunaan media sosial adalah sebesar $0,377 \geq 0,05$ maka $\mathrm{H}_{0}$ diterima dan $\mathrm{Ha}$ ditolak yang berarti tidak ada perbedaan minat wirausaha mahasiswa lima Universitas di Yogyakarta dilihat dari intensitas penggunaan media sosial.

\section{Uji ANOVA Satu Jalur}

Anova satu jalur digunakan untuk menguji perbedaan minat wirausaha mahasiswa lima universitas di Yogyakarta dilihat dari jumlah akun media sosial yang digunakan, jumlah jenis media sosial yang digunakan, dan jenis media sosial yang paling sering digunakan. Hasil pengujian dapat dilihat pada tabel 5 berikut ini :

Tabel 5. Hasil Uji Anova Satu Jalur

\begin{tabular}{ll}
\hline Keterangan & Sig. \\
\hline Berdasarkan jumlah akun media sosial yang digunakan & 0,414 \\
Berdasarkan jumlah jenis media sosial yang digunakan & 0,117 \\
Berdasarkan jenis media sosial yang paling sering digunakan. & 0,262 \\
\hline
\end{tabular}


Langkah-langkah uji Anova satu jalur

1. Berdasarkan jumlah akun media sosial yang digunakan

a. Menetapkan Hipotesis Nol $\left(\mathrm{H}_{0}\right)$ dan Hipotesis Alternatif $\left(\mathrm{H}_{1} / \mathrm{H}_{\mathrm{a}}\right)$

$\mathrm{H}_{02 \mathrm{a}}: \mu 0 a=\mu 0 b$, tidak ada perbedaan minat wirausaha mahasiswa lima Universitas di Yogyakarta dilihat dari jumlah akun media sosial yang digunakan

$\mathrm{H}_{\mathrm{a} 2 \mathrm{a}}: \mu 1 a \neq \mu 1 b$, ada perbedaan minat wirausaha mahasiswa lima Universitas di Yogyakarta dilihat dari jumlah akun media sosial yang digunakan

b. Memilih tingkat signifikansi $(\alpha)$

Tingkat signifikansi yang digunakan dalam penelitian ini yaitu $\alpha=0,05$.

c. Menentukan kriteria pengujian

Jika pSig $\geq \alpha$ maka Ho diterima dan Ha ditolak

Jika pSig $<\alpha$ maka Ho ditolak dan Ha diterima .

d. Mengambil kesimpulan

Tabel 5 menunjukkan bahwa nilai Sig untuk jumlah akun media sosial yang digunakan sebesar $0,414 \geq 0,05$ maka $\mathrm{H}_{0}$ diterima dan Ha ditolak yang berarti tidak ada perbedaan minat wirausaha mahasiswa lima Universitas di Yogyakarta dilihat dari jumlah akun media sosial yang dimiliki yaitu sebanyak 1 akun, 2 akun, 3 akun, 4 akun, ataupun lebih dari 4 akun.

2. Berdasarkan jumlah jenis media sosial yang digunakan

a. Menetapkan Hipotesis Nol (Ho) dan Hipotesis Alternatif (H1 / Ha)

$\mathrm{H}_{02 \mathrm{~b}}: \mu 0 a=\mu 0 b$, tidak ada perbedaan minat wirausaha mahasiswa lima universitas di Yogyakarta dilihat dari jumlah jenis media sosial yang digunakan

$\mathrm{H}_{\mathrm{a} 2 \mathrm{~b}}: \mu 1 a \neq \mu 1 b$, ada perbedaan minat wirausaha mahasiswa lima universitas di Yogyakarta dilihat dari jumlah jenis media sosial yang digunakan

b. Memilih tingkat signifikansi $(\alpha)$

Tingkat signifikansi yang digunakan dalam penelitian ini yaitu $\alpha=0,05$.

c. Menentukan kriteria pengujian

Jika pSig $\geq \alpha$ maka Ho diterima dan Ha ditolak

Jika pSig $<\alpha$ maka Ho ditolak dan Ha diterima 
d. Mengambil kesimpulan

Tabel 5 menunjukkan bahwa nilai Sig untuk intensitas pengunaan media sosial sebesar $0,117 \geq 0,05$ maka $\mathrm{H}_{0}$ diterima dan Ha ditolak yang berarti tidak ada perbedaan minat wirausaha mahasiswa lima Universitas di Yogyakarta dilihat dari jumlah jenis media sosial yang digunakan, baik itu yang memili 1 akun, 2 akun, 3 akun, 4 akun ataupun lebih dari 4 akun.

3. Berdasarkan jenis media sosial yang paling sering digunakan

a. Menetapkan Hipotesis Nol (Ho) dan Hipotesis Alternatif (H1 / Ha)

$\mathrm{H}_{03}: \mu 0 a=\mu 0 b$, tidak ada perbedaan minat wirausaha mahasiswa lima universitas di Yogyakarta dilihat dari jumlah jenis media sosial yang paling sering digunakan

$\mathrm{H}_{\mathrm{a} 3}: \mu 1 a \neq \mu 1 b$, ada perbedaan minat wirausaha mahasiswa lima universitas di Yogyakarta dilihat dari dari jumlah jenis media sosial yang paling sering digunakan

b. Memilih tingkat signifikansi $(\alpha)$

Tingkat signifikansi yang digunakan dalam penelitian ini yaitu $\alpha=0,05$.

c. Menentukan kriteria pengujian

Jika pSig $\geq \alpha$ maka Ho diterima dan Ha ditolak

Jika pSig $<\alpha$ maka Ho ditolak dan Ha diterima .

d. Mengambil kesimpulan

Tabel 5 menunjukkan bahwa nilai Sig untuk intensitas pengunaan media sosial sebesar 0,262 $\geq 0,05$ maka $\mathrm{H}_{0}$ diterima dan Ha ditolak yang berarti tidak ada perbedaan minat wirausaha mahasiswa lima Universitas di Yogyakarta dilihat dari jenis media sosial yang paling sering digunakan.

\section{Pembahasan Hasil Penelitian}

Hasil uji independent sample $t$ test untuk intensitas pengunaan media sosial serta uji Anova satu jalur untuk jumlah media sosial yang digunakan dan jenis media sosial yang paling sering menunjukkan bahwa tidak ada perbedaan minat wirausaha pada mahasiswa lima universitas di Yogyakarta. Ini berarti para mahasiswa di Universitas Gadjah Mada, Universitas Islam Negeri Sunan Kalijaga, Universitas Sanata 
Dharma, Universitas Atma Jaya Yogyakarta dan Universitas Sarjanawiyata Tamansiswa sama-sama memiliki minat yang tinggi untuk melakukan wirausaha karena didukung oleh adanya media sosial yang memiliki beragam fitur.

Tidak adanya perbedaan minat wirausaha pada mahasiswa lima universitas di Yogyakarta bisa terjadi karena sebagian besar sampel penelitian merupakan generasi Z. Salah satu ciri generasi $\mathrm{Z}$ adalah memiliki jiwa kewirausahaan yang tinggi karena ingin bekerja secara independen. Entrepreneur adalah pilihan terbaik kaum centennial untuk menjalani hidup, impian mereka adalah menjadi manusia yang berhasil, yang tidak bersandar pada suatu otoritas apapun yang bisa membelenggu keinginannya untuk terus bergerak maju (Wisnuhardana, 2018: 94). Ciri generasi $\mathrm{Z}$ yang memiliki jiwa kewirausahan tinggi dan keinginan untuk menjadi entrepreneur dalam menjalani hidup menjadi cerminan minat wirausaha yang tinggi.

Widiyarti (2019) juga menyatakan bahwa generasi $\mathrm{Z}$ adalah pencipta perusahaan. Terdapat sekitar $50 \%$ sampai $72 \%$ generasi $\mathrm{Z}$ yang ingin memiliki perusahaan start-up sendiri. Mereka percaya bahwa kesuksesan dapat berasal dari networking dan cenderung menyukai organisasi atau tempat kerja yang tidak memiliki hierarki. Sekitar 76 persen generasi Z memiliki keinginan agar hobinya dapat menjadi pekerjaannya. Highlight Media (2020) juga menyatakan bahwa bila dibandingkan dengan generasi $\mathrm{X}$ dan $\mathrm{Y}$ yang masih mendominasi pekerja kantoran, maka generasi $\mathrm{Z}$ lebih terbuka dalam menyikapi pilihan-pilihan yang ada di sekitarnya (https://highlight.id, 2020). Ini terjadi karena informasi terbuka lebar. Mereka menghendaki kebebasan yang lebih tinggi dari generasi milenial. Generasi Z yang dinilai bisa belajar secara otodidak secara mandiri lebih tertarik bekerja dengan metode self employee atau menjadi pekerja kreatif dengan menjadi pekerja lepas ataupun memiliki usaha sendiri.

Generasi Z memiliki semangat wirausaha (studilmu.com, 2019). Di saat sebagian generasi $\mathrm{Z}$ berencana untuk bekerja di perusahaan sepanjang karier mereka, mereka juga melatih diri untuk berpikir sebagai wirausahawan. Ada sebanyak $72 \%$ dari mereka berharap dapat memulai bisnis sendiri di kemudian hari dan $61 \%$ berencana untuk menjalani bisnis sendiri setelah mereka lulus kuliah. 


\section{Kesimpulan, Implikasi, Saran dan Keterbatasan}

Berdasarkan hasil analisis deskriptif dapat disimpulkan bahwa mayoritas mahasiswa menggunakan media sosial dengan intensitas 3 jam atau lebih/hari, memiliki jumlah media sosial yang meliputi jumlah akun dan jumlah jenis media sosial sebanyak lebih dari 4, paling sering menggunakan jenis media sosial WhatsApp dan Line, dan secara umum mahasiswa memiliki minat wirausaha yang tinggi. Berdasarkan hasil uji hipotesis dengan independent sample t-test dan Anova satu jalur, penelitian ini menyimpulkan bahwa tidak ada perbedaan minat wirausaha mahasiswa pada mahasiswa lima Universitas di Yogyakarta dilihat dari penggunaan media sosial.

Hasil penelitian ini menunjukkan bahwa rata-rata skor tertinggi berada pada komponen konatif yang menandakan bahwa mayoritas mahasiswa lebih menyukai praktek secara langsung. Oleh sebab itu, pihak universitas sebaiknya memperbanyak kegiatan praktek berkaitan dengan kewirausahaan. Misalnya pada matakuliah Kewirausahaan mahasiswa lebih banyak didorong untuk praktek membuka usaha dibandingkan dengan menerima teori di kelas. Selain itu, sebaiknya mahasiswa lebih banyak memanfaatkan media sosial untuk mengembangkan bisnis yang sedang dirintisnya. Hal ini karena penelitian ini menemukan bahwa generasi Z memiliki intensitas penggunaan media sosial 3 jam atau lebih setiap harinya, memiliki lebih dari 4 akun media sosial, menggunakan lebih dari 4 jenis media sosial. Selain itu, generasi $\mathrm{Z}$ juga paling banyak menggunakan WhatsApp dan Line sehingga mahasiswa bisa memanfaatkan berbagai fitur yang ada di WhatsApp dan Line untuk melakukan berbagai kegiatan wirausaha.

Penelitian selanjutnya disarankan menggunakan kuesioner yang sudah ada di jurnal terutama jurnal internasional. Penelitian dengan topik yang sama dapat menambahkan variabel independen sehingga informasi dan pengetahuan yang diterima menjadi lebih lengkap dan bertambah. Selain itu, jika tertarik untuk menggunakan populasi yang serupa sebaiknya menggunakan lebih banyak sampel agar benar-benar mampu mewakili jumlah populasi sehingga data yang diperoleh lebih akurat. Penelitian ini hanya meneliti 100 mahasiswa dari lima universitas di Yogyakarta yang jumlah populasinya sebesar 114.225 mahasiswa. Sebaiknya peneliti berikutnya meninjau ulang karakteristik sampel karena penelitian ini hanya 
mengambil sampel dari generasi $\mathrm{Z}$ yang memiliki karakteristik minat berwirausaha yang tinggi.

Keterbatasan penelitian ini adalah sampel ditentukan dengan tingkat kepercayaan $95 \%$ dan tingkat eror sebesar 10\% sehingga sampel yang diterima belum seutuhnya mewakili seluruh jumlah populasi yang ada dan karena hal tersebut penelitian ini memiliki resiko tingkat eror yang besar. Selain itu, pada penelitian ini peneliti hanya terfokus pada variabel penggunaan media sosial yang mencakup intensitas penggunaan, jumlah media sosial, dan jenis media sosial yang paling sering digunakan untuk mengetahui perbedaan minat wirausaha mahasiswa, sehingga mengabaikan kemungkinan adanya variabel lain yang bisa menyebabkan adanya perbedaan minat wirausaha mahasiswa. Sampel penelitian ini hanya mewakili satu jenis generasi yaitu generasi $\mathrm{Z}$

\section{Referensi}

Afriani, Gusti Leni. (2015). Pengaruh Persepsi Siswa Tentang Metode Guru Dalam Mengajar, Jiwa Kewirausahaan, dan Penggunaan Media Sosial terhadap Minat Berwirausaha Siswa Kelas XI Akuntansi SMK Negeri 1 Depok Tahun Ajaran 2014/2015 Fakultas Ekonomi Universitas Negeri Yogyakarta. Yogyakarta: Universitas Negeri Yogyakarta.

Basrowi. (2011). Kewirausahaan Untuk Perguruan Tinggi. Bogor: Penerbit Ghalia Hendro. 2011. Dasar-Dasar Kewirausahaan Panduan bagi Mahasiswa untuk Mengenal, Memahami, dan Memasuki Dunia Bisnis. Jakarta: Erlangga.

Hertanto, Eko. (2017). Perbedaan Skala Likert Lima Skala dengan Modifikasi Skala Likert Empat Skala. Jurnal Metodologi Penelitian. 1(1), 1-4

Indoworo, Hawik Ervina. (2016). Menumbuhkan Jiwa Wirausaha Melalui Peran Sosial Media. Jurnal Informatika UPGRIS, 2 (1), 45-55.

Indrawan, Ruli dan Yuniawati Poppy. 2017. Metodologi Penelitian Kuantitatif, Kualitatif, dan Campuran untuk Manajemen, Pembangunan, dan Pendidikan. Bandung: PT Refika Aditama.

Kurniawan, Yusril Rosyid dan Harti. (2013). Pengaruh Tingkat Penggunaan Sosial Media Terhadap Minat Berwirausaha Pada Mahasiswa Pendidikan Ekonomi Universitas Negeri Surabaya. Jurnal Pendidikan Tata Niaga.1(3), 1-17.

Martono, Nanang. 2014. Metode Penelitian Kuantitatif Analisis Isi dan Analisis Data Sekunder. Depok: PT Rajagrafindo Persada.

Nova, Sari Putri. 2018. "Efektivitas Komunikasi Aplikasi Telegram Sebagai Media Informasi Pegawai PT.POS Indonesia (PERSERO) Kota Pekanbaru" Jurnal FISIP, 1 (4), 1-11.

Rahayu, Ajeng. (2015). Minat Berwirausaha Mahasiswa Program Studi Administrasi Bisnis Jurusan Administrasi Niaga Politeknik Negeri Bandung Angkatan 2013 \& 2014. Jurnal Program Studi Administrasi Bisnis DIII, 1-17.

Sugiyono. 2018. Metode Penelitian Kombinasi. Bandung: Alfabeta. 
Wisnuhardana, Aloys. 2018. Anak Muda dan MedSos. Jakarta : PT Gramedia Pustaka Utama.

Yahmini, Exnasiyah. 2018. Kecenderungan Impulsive Buying Pada Mahasiswa Ditinjau Dari Latar Belakang Keluarga Fakultas Ekonomi Universitas Sanata Dharma. Yogyakarta: Universitas Sanata Dharma

Sumber Internet:

Kevin, Anthony. 2019. Disebut Pemerintah Rendah, Pengangguran RI Tertinggi di ASEAN. www.cnbcindonesia.com. diakses tanggal 8 Oktober 2019.

Badan Pusat Statistik. 2019. Tingkat Pengangguran Terbuka. https://www.bps.go.id. diakses tanggal 12 Agustus 2019.

Ristekdikti. 2019. Jumlah Mahasiswa. https://forlap.ristekdikti.go.id. Diakses tanggal 20 Juli 2019.

Widiyarti, Yayuk. 2019. Mengenal Karakter Generasi Z, Mandiri, Keras Kepala Tapi Inovatif. https://cantik.tempo.co. diakses tanggal 16 Juni 2020.

Pertiwi, Wahyunanda Kusuma. 2018. Riset Ungkap Pola Pemakaian Medsos Orang Indonesia. https://tekno.kompas.com. diakses tanggal 16 Juni 2020.

https://apjii.or.id, diakses tanggal 8 Oktober 2019

wearesocial.com diakses tanggal 8 Oktober 2019

kompas.com diakses tanggal 8 Oktober 2019

Studilmu.com, diakses tanggal 8 Juni 2020

https://highlight.id, diakses tanggal 8 Juni 2020 